\title{
RESILIENSI PADA REMAJA PUTRI YANG MENGALAMI KEHAMILAN TIDAK DIINGINKAN AKIBAT KEKERASAN SEKSUAL
}

\author{
Disa Dwi Fajrina \\ Psikologi, Fakultas Ilmu Pendidikan, Universitas Negeri Jakarta \\ Jl. Rawamangun Muka, Jakarta Timur \\ Email:disadwifajrina@ymail.com
}

\begin{abstract}
This study aims to provide an overview of resilience in teenagers girl who experience unwanted pregnancy due to sexual abuse. The approach used in this study is a qualitative approach with a qualitative case study approach. Data collection techniques used were interviews, observation and documentation. Data were analyzed using qualitative data analysis techniques and techniques of data validity checks using triangulation. These results indicate that both the resilience so that the subject has the ability to positively adapt to the event of unwanted pregnancy due to sexual abuse. Subject I adapt to calm down and think over the matter while subject II adapting to talk to someone nearby. Both subjects also have a seventh aspect of building resilience with the capability of different quality. The subject I is better to regulate and control the negative impulse that is felt while subject II more visible sense of optimism and efficacy of the problem itself. The results also showed that support from the nearest such as family, friends, is one of the most influential factor on the development of resilience both subjects.
\end{abstract}

Keywords: Resilience, teenagers girl, unwanted pregnancy, sexual abuse

\section{Pendahuluan}

Kehamilan merupakan dambaan bagi setiap wanita dan tentunya bagi mereka yang telah menikah, namun luapan perasaan terasa berbeda apabila pada usia remaja mengalami kehamilan tidak diinginkan akibat dari kekerasan seksual. Pada dasarnya, kekerasan seksual adalah setiap bentuk perilaku yang memiliki muatan seksual secara paksa yang dilakukan oleh seseorang atau sejumlah orang namun tidak disukai dan tidak diharapkan oleh orang yang menjadi sasaran sehingga menimbulkan akibat negatif, seperti rasa malu, tersinggung, terhina, marah, kehilangan harga diri, kehilangan kesucian hingga mengalami kehamilan pada diri orang yang menjadi korban (Supardi \& Sadarjoen, 2006). Beberapa kasus mengenai tindakan kekerasan seksual sebagian besar dialami oleh kaum perempuan. Salah satunya, dalam Laporan Khusus Komnas Perempuan tentang Kekerasan Seksual (2008) yang terjadi pada kerusuhan Mei 1998 menegaskan bahwa telah terjadi kekerasan seksual termasuk pemerkosaan didalam rangkaian kerusuhan Mei 1998 pada perempuan etnis Tionghoa dari usia anak, remaja sampai dewasa. Meskipun tidak ada jumlah yang pasti, hasil laporan ini menunjukkan bahwa jumlah korban dapat lebih dari yang pernah dilaporkan, termasuk oleh TGPF Mei 1998 yang menyebutkan adanya 85 orang perempuan korban kekerasan seksual. Serangan seksual dalam rangkaian kerusuhan Mei 1998 terjadi dalam bentuk kekerasan seksual dimana didalamnya terdapat ancaman perkosaan hingga tindak pemaksaan oral seks dan penganiayaan seksual dimana vagina dirusak dengan menggunakan berbagai benda.

Dalam Laporan Khusus Komnas Perempuan tentang Kekerasan Seksual (2008) yang terjadi pada kerusuhan Mei 1998 juga menyebutkan bahwa dampak dari kejadian kekerasan seksual yang dialami oleh korban adalah takut terkena penyakit menular dan terjadinya kehamilan tidak diinginkan. 
Dalam kasus lain, remaja mengalami kehamilan akibat tindak kekerasan dalam berhubungan seksual. Hasil riset yang dilakukan BKKBN (2010) di Jakarta menyebutkan pada tahun 2010, 51\% remaja putri mengalami kasus hamil tidak diinginkan sebelum menikah. Rata-rata terdapat 17 $\%$ kehamilan tidak diinginkan akibat kekerasan seksual yang dialami remaja putri.

Balai Besar Penelitian dan Pengembangan Pelayanan Kesejahteraan Sosial dan Departemen Sosial Republik Indonesia (BKKBN, 2008) juga melakukan penelitian yang bertujuan untuk mengetahui perkembangan kasus-kasus kehamilan pada remaja putri usia 10-24 tahun. Hasil penelitian menunjukkan bahwa tahun 2002-2005, remaja putri yang mengalami kehamilan tidak diinginkan akibat kekerasan seksual dari pasangan sebanyak 35\%.

Berdasarkan data penelitian tersebut, kekerasan seksual telah menimbulkan dampak kehamilan yang tidak diinginkan pada kaum perempuan terlebih remaja putri. Kehamilan yang terjadi adalah bukan kehamilan yang diinginkan oleh setiap pasangan yang telah menikah pada umumnya melainkan kehamilan terjadi akibat kekerasan seksual dalam berhubungan diluar sebuah pernikahan. Kehamilan tidak diinginkan tersebut terjadi akibat kekerasan secara seksual serta paksaan yang dialami oleh remaja putri disaat belum menikah.

Secara umum, kehamilan tidak diinginkan merupakan suatu kondisi dimana pasangan tidak mengkehendaki adanya kelahiran akibat dari suatu kehamilan baik bagi pasangan yang sudah menikah ataupun belum menikah (DepKesRI, 2007). Salah satu faktor yang menyebabkan kehamilan tidak iinginkan adalah kehamilan yang diakibatkan oleh kekerasan dalam berhubungan seksual diluar pernikahan.

Kehamilan tidak diinginkan sebagian besar dialami oleh remaja putri. Kehamilan tidak diinginkan yang dialami oleh remaja putri terjadi akibat kekerasan seksual yang disertai paksaan dalam berhubungan seksual. Kekerasan seksual dapat terjadi ketika pelaku memiliki kekuasaan yang lebih daripada remaja putri. Kekuasaan dapat berupa posisi pekerjaan yang lebih tinggi, kekuasaan ekonomi dan kekuasaan jenis kelamin (Wardhani \& Lestari, 2009). Bahkan kekerasan seksual yang banyak terjadi dilakukan oleh pasangan remaja putri itu sendiri (BKKBN, 2008). Pasangan yang melakukan hubungan seksual seperti mencium tanpa persetujuan, sentuhan dibagian sensitif tanpa persetujuan, hingga berhubungan seksual tanpa ijin dapat dikatakan juga sebagai pemaksaan dalam kegiatan atau kontak seksual apabila salah satu pihak pasangan tidak menghendakinya (Murray, 2007). Remaja putri akan merasa takut apabila pasangan akan memutuskan hubungan dan melakukan hal yang lebih parah jika remaja putri menolak sehingga pasangan melakukan apapun sesukanya dengan bebas (Juniarsih, 2011).

Beberapa remaja putri yang mengalami kehamilan tidak diinginkan akibat kekerasan seksual berupa paksaan dalam melakukan hubungan seksual mengakui bahwa telah adanya unsur paksa dalam melakukan hubungan seksual dari pasangan.

Remaja putri yang mengalami kehamilan tidak diinginkan akibat kekerasaan seksual, beberapa diantaranya juga ditinggalkan oleh pasangan. Pasangan yang diharapkan oleh remaja putri untuk bertanggung jawab atas kehamilannya memilih pergi, menyarankan untuk menggugurkan kehamilan dan membiarkan remaja putri menanggung kehamilan serta dampak dari kehamilan tidak diinginkan tersebut seorang diri. Dina (2008) menyatakan bahwa remaja putri mengalami kehamilan tidak diinginkan menghadapi dilema sebab apabila hubungan berakhir akan terjadi luka dan trauma yang cukup medalam.

Reivich dan Shatte (2002) mengemukakan beberapa emosi yang biasa dialami oleh remaja putri karena kandasnya hubungan percintaan setelah terjadinya kehamilan tidak diinginkan, yaitu kesedihan dan depresi, perasaan bersalah, marah, kecemasan dan juga perasaan malu. Perubahan mood yang kuat, cepat dan sering, perasaan mudah tersinggung, kesepian, mengalami masalah yang berkaitan dengan pola tidur dan nafsu makan, merasa putus asa dan bingung.

Remaja putri yang mengalami kehamilan tidak diinginkan akibat kekerasan dari pasangan membuat remaja putri harus menanggung kehamilannya diusia yang masih belia seorang diri bahkan tanpa pasangan. Beberapa dampak yang membahayakan keselamatan remaja putri yang mengalami kehamilan juga turut mengancam. Sistem hormonal remaja putri juga belum stabil yang ditandai dengan belum teraturnya haid. Ketidakteraturan hormon tersebut akan membuat kehamilan menjadi tidak stabil, mudah terjadi perdarahan dan keguguran atau kematian (DepKes RI, 2007). McKenry, Walters dan Johnson (dalam Papalia dan Olds, 2001) juga menyatakan bahwa kehamilan pada remaja putri yang tidak diinginkan memiliki dampak tertentu seperti ketidaksiapan untuk melahirkan. Ketidaksiapan tersebut sangat mempengaruhi kondisi psikologis remaja putri.

Kehamilan yang tidak diinginkan akibat kekerasan seksual dari pasangan mempengaruhi kondisi psikologis remaja putri sehingga telah menimbulkan posisi remaja putri dalam situasi yang serba salah dan memberikan tekanan batin, 
depresi, gangguan psikologis yang sangat berbahaya, marah pada diri sendiri, pada pasangan atau orang yang menyebabkan kehamilannya. Situasi yang dirasa remaja tersebut disebabkan oleh beberapa faktor, yaitu seperti malu karena kehamilannya adalah sebuah aib, takut tidak diterima oleh dari keluarga dan masyarakat, terpaksa harus keluar dari sekolah, terganggunya perekonomian keluarga dan persalinan yang tidak dipersiapkan. Adanya keinginan untuk menggugurkan kandungan yang dapat mengancam jiwa remaja, cacat janin, perdarahan dan gangguan masa nifas. Terakhir, adanya pandangan remaja bahwa kehamilan yang tidak diinginkan dapat mempengaruhi pendidikan, rencana karier, kecemasan dalam menghadapi kehamilan, persalinan dan masa depannya (Manuaba, 1999).

Remaja putri yang mengalami kehamilan tidak diinginkan tidak mendapatkan pertanggungjawaban dari pasangannya dihadapkan oleh dua pilihan, yaitu tetap melanjutkan kehamilan dengan konsekuensi mendapatkan aib dan tekanan masyarakat atau melakukan tindakan anarki seperti menggugurkan kandungan dengan resiko bahaya kesehatan dan keselamatan (Yuarsi, 2005).

Beberapa dari remaja putri yang mengalami kehamilan tidak diinginkan akibat kekerasaan seksual melakukan tindakan anarki dan percobaan bunuh diri. Tindakan anarki yang biasa dilakukan oleh remaja putri adalah dengan menggugurkan kandungan (aborsi) dan pembunuhan bayi, sebab itu adalah satu-satunya cara untuk meringankan dampak negatif dari kehamilan yang tidak diinginkan dan menghindari ketidaksiapan menjadi orang tua.

Tindakan anarki lainnya adalah percobaan bunuh diri yang dilakukan oleh remaja putri di Pontianak, remaja yang masih berusia 18 tahun mencoba melakukan bunuh diri dengan cara meminum racun nyamuk karena malu mengandung janin yang tidak diinginkan akibat hubungan paksa yang dilakukan pasangannya. Remaja putri tersebut menenggak racun dan seketika tak sadarkan diri (Pontianak Post, 2012).

Berbagai tindakan anarki dilakukan remaja putri untuk menghindari konsekuensi berat dalam hidupnya. Tidak mudah bagi remaja putri yang hamil akibat kekerasan seksual memperoleh suami. Bisa saja remaja putri yang mengalami kehamilan tidak diinginkan tersebut menikah dengan pasangan yang telah menyebabkan kehamilannya, namun bukan hal yang mudah untuk membangun bahtera perkawinan dengan seseorang yang pernah menghamilinya melalui kekerasan seksual. Fakta lainnya telah menyebutkan beberapa remaja justru ditinggalkan oleh pasangan yang menyebabkan kehamilannya.
Kekerasan seksual yang dialami remaja putri juga dapat menimbulkan efek trauma yang mendalam. Remaja putri yang mengalami kehamilan tidak diinginkan akibat kekerasan seksual yang terjadi dapat mengalami stres. Keputusan untuk tetap melahirkan merupakan keputusan yang tidak mudah apalagi menerima kenyataan bahwa bayi yang dilahirkannya adalah hasil hubungan yang tidak diinginkan. Kehamilan tidak diinginkan akibat dari kekerasaan seksual yang terjadi merupakan sesuatu yang dapat mempengaruhi hidup remaja putri seumur hidup. Remaja putri yang mengalami kekerasan seksual mengalami stres karena peristiwa tersebut merupakan peristiwa traumatis yang sangat membekas bagi dirinya. Ketika seseorang mengalami kekerasan secara seksual secara fisik maupun psikologis, maka kejadian tersebut dapat menimbulkan suatu trauma yang sangat mendalam dalam diri seseorang tersebut terutama pada remaja (Wardhani \& Lestari, 2009).

Beberapa remaja putri lain yang mengalami kehamilan tidak diinginkan akibat kekerasaan seksual dari pasangannya memilih untuk tetap melanjutkan kehamilan walaupun dengan konsekuensi mendapatkan aib dan tekanan masyarakat.

Remaja putri tersebut merasakan perasaan malu, sedih, kecewa, rasa bersalah, tertekan dan perasaan negatif lainnya, tetapi mereka tidak membiarkan perasaan-perasaan negatif berada pada dalam dirinya berlarut. Remaja putri yang mengalami kehamilan tidak diinginkan akibat kekerasaan seksual dari pasangannya berusaha untuk bertahan dan bangkit dari keadaan yang tertekan. Kemampuan untuk mengatasi, beradaptasi serta bertahan dalam keadaan tertekan dan bahkan berhadapan dengan kesengsaraan (adversity) atau trauma yang dialami dalam kehidupannya disebut resiliensi (Reivich dan Shatte, 2002).

Dari penelitian yang dilakukan oleh Tugade dan Frederickson (2004) dinyatakan bahwa seorang individu yang resilien akan menyadari bahwa regulasi emosi positif lebih berguna daripada emosi negatif. Dalam penelitian tersebut dikatakan bahwa individu yang resilien dapat mengatasi pengalaman buruknya secara lebih baik, ketika individu lain mengalami kondisi serupa dan tidak dapat mengatasinya sebaik individu yang resilien. Remaja putri yang resilien akan berusaha dengan sekuat tenaganya untuk bangkit dan menghadapi kesulitan atas kehamilan tidak diinginkan akibat kekerasan seksual dari pasangan, bahkan mampu mengatasi kesulitannya tersebut dan mengubahnya menjadi sesuatu yang positif. Oleh sebab itu, ada remaja putri yang mampu bertahan dan pulih dari situasi negatif secara efektif dan ada remaja putri lain yang gagal karena mereka tidak berhasil keluar dari 
kesulitan atas kehamilan tidak diinginkan akibat kekerasan seksual dari pasangan.

Secara umum, resiliensi bermakna kemampuan seseorang untuk bangkit dari keterpurukan yang terjadi dalam kehidupannya. Individu dengan resiliensi yang positif mampu mengelola emosi mereka secara sehat. Remaja putri yang mengalami kehamilan tidak diinginkan akibat kekerasan seksual dari pasangannya juga merasakan perasaan sedih, marah, merasa kehilangan, sakit hati dan tertekan. Dilain sisi, remaja putri tidak membiarkan perasaan semacam itu menetap dalam waktu lama. Remaja putri tersebut cepat memutus perasaan yang tidak nyaman dan tidak sehat, kemudian justru membantunya bertumbuh menjadi individu yang lebih kuat.

Remaja putri tersebut tentunya mengalami proses stres, mereka harus beradaptasi, menerima kenyataan dengan keadaannya dan meneruskan kehamilan yang memang tidak diinginkan, melahirkan, mengasuh anaknya sendiri dan menjadi orang tua bagi anak dari kehamilannya tersebut. Bahkan sebagian dari mereka tetap mengembangkan pendidikan maupun kariernya sambil menyandang status ibu. Remaja putri yang mampu melewati masa-masa sulit atas kehamilan tidak diinginkan akibat kekerasan seksual dari pasangan menampakkan perilaku positif. Remaja putri tersebut mampu menyesuaikan diri dengan keadaan yang tidak menyenangkan, melewati keadaan yang tidak menyenangkan tersebut dengan baik bahkan menerima kehamilan yang tidak diinginkan tersebut menjadi bagian dari hidupnya dengan merawat kehamilan hingga anak tersebut besar. Proses pengambilan keputusan sampai remaja putri dapat menerima kenyataan dan bertanggung jawab sebagai orang tua serta menjadi orang yang lebih baik merupakan salah satu kemampuan individu yang resilien (Reivich dan Shatte, 2002).

Kemampuan remaja putri untuk melanjutkan hidup setelah ditimpa kemalangan atau setelah mengalami tekanan yang berat seperti kesulitannya menghadapi kehamilan tidak diinginkan akibat kekerasan seksual dari pasangannya bukanlah sebuah keberuntungan, tetapi hal tersebut menggambarkan adanya kemampuan tertentu pada individu (Tugade \& Fredrikson, 2004). Resiliensi adalah keterampilan yang penting untuk dikembangkan disegala sektor kehidupan. Adapun beberapa ciri utama pribadi dengan resiliensi tinggi itu berkisar pada kemampuan mempertahankan perasaan positif dan juga kesehatan serta energi. Individu yang resilien juga memiliki kemampuan memecahkan masalah yang baik, berkembangnya harga diri, konsep diri dan kepercayaan diri secara optimal. Oleh karena itu, resiliensi merupakan faktor penting dalam proses perkembangan psikologis untuk kembali memperbaiki keadaan dan menerima kenyataan bagi remaja putri yang mengalami kehamilan tidak diinginkan akibat kekerasan seksual dari pasangannya.

\section{Metode Penelitian}

Pendekatan yang digunakan dalam penelitian ini adalah pendekatan secara kualitatif sebagaimana yang dikemukakan oleh Creswell (2010) bahwa pendekatan kualitatif digunakan untuk memahami makna dari masalah sosial yang terjadi pada sejumlah individu atau sekelompok orang. Dalam penelitian ini, masalah sosial yang diangkat mengenai resiliensi pada remaja yang mengalami kehamilan tidak diinginkan akibat kekerasan seksual. Resiliensi itu sendiri bersifat subjektif sebab setiap individu memiliki permasalahan yang berbeda-beda. Resiliensi juga bersifat dinamis, dapat berubah sesuai dengan kondisi yang berkembang setiap individu. Oleh karena itu, dalam prosesnya dibutuhkan pendekatan kualitiatif yang cocok digunakan untuk memahami manusia dalam segala kompleksitasnya sebagai mahkluk subjektif dan digunakan untuk hal yang membutuhkan pemahaman secara mendalam dan khusus (Poerwandari, 2009).

Metode penelitian yang digunakan yaitu studi kasus, yaitu suatu penelitian dimana peneliti menyelediki secara cermat suatu aktivitas sejumlah individu (Creswell, 2010). Peneliti mengumpulkan informasi secara lengkap dengan menggunakan berbagai prosedur pengumpulan data berdasarkan waktu yang telah ditentukan (Stake dalam Creswell, 2010).

Dalam penelitian ini, peneliti mengambil subjek remaja yang mengalami kehamilan tidak diinginkan akibat kekerasan seksual sebanyak 2 orang dengan pertimbangan bahwa jumlah tersebut dapat memperlihatkan gambaran yang lebih menyeluruh terhadap resiliensi remaja yang mengalami kehamilan tidak diinginkan akibat kekerasan seksual.

Proses pengambilan data dalam penelitian ini juga menggunakan observasi, wawancara, dan dokumentasi. Observasi dilakukan untuk melengkapi dan memperoleh data tentang hal yang tidak diungkapkan oleh partisipan secara terbuka dalam wawancara (Creswell, 2010). Dalam penelitian ini observasi yang dilakukan adalah non partisipatif dan dituliskan secara naratif, yaitu observer tidak ikut melakukan apa yang dilakukan oleh subjek penelitian.

Dalam penelitian ini, bentuk wawancara yang digunakan adalah wawancara semi terstruktur yaitu peneliti merancang serangkaian pertanyaan yang 
disusun dalam suatu daftar wawancara akan tetapi daftar tersebut digunakan untuk menuntun bukan untuk mendikte wawancara tersebut (Smith, 2009).

Oleh karena itu, dalam proses wawancara ini peneliti melengkapi dengan pedoman wawancara yang sangat umum berkenaan topik penelitian tanpa menentukan urutan pertanyaan. Menurut Poerwandari (2009), pedoman wawancara digunakan untuk mengingatkan peneliti mengenai aspek-aspek yang harus dibahas dalam proses wawancara dan juga sebagai daftar pengecek apakah aspek-aspek relevan tersebut telah dibahas atau telah ditanyakan. Prosedur pengumpulan data yang ketiga adalah dokumentasi dengan materi audio dan visual. Dalam penelitian ini dokumentasi dilakukan dengan materi audio berupa rekaman suara subjek.

Dalam penelitian ini, peneliti melakukan triangulasi sumber data dan triangulasi metode. Triangulasi sumber data yaitu mengambil data dari subjek penelitian dan dari orang-orang terdekat subjek. Triangulasi metode yaitu mengambil data dengan wawancara, observasi dan dokumentasi.

\section{Hasil \& Diskusi}

Menurut Reivich dan Shatte (2002), regulasi emosi adalah kemampuan untuk tetap tenang dibawah tekanan. Individu yang memiliki kemampuan meregulasi emosi dapat mengendalikan dirinya apabila sedang kesal dan dapat mengatasi rasa cemas, sedih atau marah sehingga mempercepat dalam pemecahan suatu masalah. Walaupun subjek I sempat merasakan perasaan sedih, marah, malu bahkan terlintas dibenakknya untuk bunuh diri dan menggugurkan kandungan, namun subjek I dapat segera mengatasi perasaan-perasaan negatif tersebut. Subjek I meregulasi emosinya dengan memilih untuk bersikap tenang dengan cara diam sambil terus berpikir mencari jalan keluar terhadap masalah kehamilan tidak diinginkan yang dialaminya. Jalan keluar tersebut didapatkan oleh SR ketika dirinya memutuskan untuk bercerita kepada ibu penjaga di sekolahnya.

Sama halnya dengan subjek I, subjek II juga merasakan perasaan-perasaan negatif seperti rasa sedih, marah, malu, takut dan lain-lain. Subjek II meregulasi emosinya tersebut dengan cara mencari tempat yang tepat untuk meredam semua perasaanpreasaan negatifnya. Subjek II menjatuhkan pilihan dengan bercerita kepada tetangga yang sudah subjek II anggap sebagai kakaknya sendiri untuk mencari jalan keluar.
Reivich dan Shatte (2002) juga memberikan definisi dari pengendalian impuls sebagai kemampuan individu untuk mengendalikan keinginan, dorongan, kesukaan, serta tekanan yang muncul dari dalam diri. Dorongan-dorongan perasaan negatif yang muncul dari tekanan dalam diri subjek I seperti rasa amarah, sedih, perasaan bersalah, keinginan untuk bertindak anarki atas kehamilan tidak diinginkan yang dialaminya dapat dikendalikan oleh subjek I. Subjek I terus berusaha untuk tenang dengan cara berdiam diri menenangkan pikiran tanpa ada orang lain yang mengganggunya.

Subjek II juga merasakan dorongan-dorongan dari perasaan negatif yang muncul akibat dari berbagai rasa tertekan yang dirasakan subjek II. Rasa sedih, kecewa, malu, takut, merasa berdosa terus meletup-letup namun subjek II berusaha untuk bersikap tenang dan tidak gegabah dengan menenangkan pikiran. Salah satu cara subjek II menenangkan pikiran adalah dengan berbagi apa yang sedang dirasakannya dengan orang yang paling dekat dengan subjek II.

Ketika individu melihat bahwa masa depan dirinya cemerlang dan percaya bahwa dirinya dapat menangani masalah-masalah yang muncul dimasa yang akan datang merupakan definisi optimisme menurut Reivich dan Shatte (2002). Subjek I optimis dengan masa depannya sebab akan meneruskan ujian kelulusan sekolah dan bekerja agar dapat hidup bahagia dengan anaknya. Subjek I juga yakin bahwa dirinya dapat melewati lika-liku kehidupannya nanti bersama orang-orang terdekat.

Tidak jauh subjek II juga sangat optimis dengan kehidupannya nanti bahwa masa depannya akan berubah lebih baik dari sekarang. Subjek II akan berusaha untuk bekerja gara dapat memenuhi kebutuhan anaknya kelak.

Menurut Reivich dan Shatte (2002), empati sangat erat kaitannya dengan kemampuan untuk membaca tanda-tanda emosi dan psikologis orang lain. Empati mencerminkan seberapa baik individu mengenali bahasa-bahsa non verbal yang ditunjukkan oleh orang lain. Werner dan Smith (dalam Reivich dan Shatte, 2002) juga menambahkan individu yang berempati mampu mendengarkan dan memahami orang lain sehingga mendatangkan reaksi yang positif dari lingkungan.

Subjek I sangat memahami dan merasakan kesedihan, kekecewaan dan kemurkaan keluarganya terhadap dirinya atas kesalahan yang telah dilakukan oleh dirinya. Bahkan subjek I juga memposisikan jika dirinya memiliki anak yang mengalami kehamilan tidak diinginkan. Subjek I sangat sedih ketika dirinya telah mengecewakan keluarga terutama ibunya dan berusaha untuk meminta maaf kepada seluruh keluarganya dan 
menyadari kesalahannya. Tidak sebatas itu usaha yang dilakukan oleh subjek I juga mencari tambahan uang agar dirinya tidak terlalu bergantung dan meringankan beban orang tuanya.

Subjek II juga sangat memahami kesedihan, kekecewaan dan kemurkaaan yang dirasakan oleh keluarganya. Subjek II sangat sedih dan merasa telah mengecewakan keluarganya dan berusaha untuk meminta maaf kepada kedua orang tuanya terutama ibu. Subjek II juga memperlihatkan rasa kepedulian terhadap keluarga dengan bekerja menambah penghasilan untuk membantu biaya keluarganya.

Menurut Reivich dan Shatte (2002), analisis penyebab masalah menggambarkan kemampuan individu untuk mengidentifikasikan secara akurat penyebab dari permasalahan yang mereka hadapi. Individu yang tidak mampu mengidentifikasikan penyebab dari permasalahan yang mereka hadapi secara tepat, dirinya akan cenderung mengulang kesalahan yang sama. Kedua subjek mampu mengidentifikasi penyebab kehamilan tidak diinginkan mereka. Mereka dapat mengidentifikasi penyebab kehamilan tidak diinginkan yaitu karena melakukan hubungan yang seharusnya tidak boleh dilakukan sebelum menikah dan terlalu rela berkorban kepada seseorang yang baru dianggap kekasih. Kedua subjek juga percaya bahwa semua yang terjadi adalah atas kehendak Tuhan.

Individu yang resilien adalah individu yang memiliki fleksibilitas kognisi dan mampu mengidentifikasi semua penyebab yang signifikan dalam permasalahan yang mereka hadapi tanpa terperangkap dalam explanatory style tertentu.

Subjek I cenderung memiliki fleksibilitas kognisi dalam dimensi personal (saya-bukan-saya) Subjek I menyadari bahwa dirinya sendiri yang menyebabkan terjadinya kehamilan tidak diinginkan. Disamping itu, SR berpikir bahwa dia harus memikirkan bagaimana kehidupannya nanti dan tidak perlu unuk mencari kambing hitam dalam penyebab kehamilannya.

Subjek I juga cenderung memiliki fleksibilitas kognisi dalam permanen (selalu-tidak selalu). Subjek I pun merasa kehamilan tidak diinginkan yang dialami bukan merupakan akhir kehidupannya. SR optimis bahwa semua itu adalah ujian dari Tuhan dan dirinya harus berusaha mencari solusi dari ujian yang diberikan oleh Tuhan bukan menjadikan masalah kehamilan dirinya sebagai suatu hambatan.

Fleksibilitas kognisi subjek I dalam dimensi pervasif (semua-tidak semua), pada awalnya subjek I menganggap bahwa kehamilan tidak diinginkan yang dialami adalah suatu awal mula kehidupan yang suram, namun dengan selalu berbagi cerita dengan orang terdekat dirinya dapat bangkit dan menjadi orang yang lebih baik.

Subjek II cenderung memiliki fleksibilitas kognisi dalam dimensi personal (saya-bukan-saya) Subjek II menyadari bahwa kecerobohan dirinya ikut andil dalam hal yang menyebabkan terjadinya kehamilan tidak diinginkan. Subjek II sendiri tidak dapat mempersalahkan sepenuhnya kepada kekasihnya.

Selain itu, subjek II juga cenderung memiliki fleksibilitas kognisi dalam permanen (selalu-tidak selalu). Subjek II berpikir bahwa dengan mengalami permasalahan kehamilan tidak diinginkan, hidupnya akan selalu bermasalah. Namun akhirnya subjek II yakin hidupnya akan berubah jika mau berusaha untuk menjadi lebih baik dari sebelumnya dan juga percaya setiap masalah pasti ada solusinya sehingga hidup tidak selalu penuh masalah. Subjek II yakin bahwa dirinya dapat melewati permasalahannya dengan terus berusaha untuk memperbaiki diri.

Fleksibilitas kognisi PL dalam dimensi pervasif (semua-tidak semua), pada awalnya PL merasa kehamilan diluar pernikahan yang dialami adalah akhir dari kehidupannya, namun semakin lama PL merasa bahwa bukan saatnya unutk terus dalam keadaan yang seperti itu. PL yakin bahwa dirinya dapat melewati permasalahannya dengan terus berusaha untuk memperbaiki diri.

Reivich dan Shatte (2002) mendefinisikan efikasi diri adalah keyakinan pada kemampuan diri sendiri bahwa mampu menghadapi dan memecahkan masalah dengan efektif. Efikasi diri juga berarti meyakini diri sendiri mampu berhasil dan sukses. SR memiliki keyakinan bahwa dirinya dapat menyelesaikan masalah yang sedang dihadapinya, sebab subjek memiliki keluarga dan teman yang siap membantunya kapan saja. SR yakin dengan dirinya sendiri bahwa dirinya dapat membesarkan anakya hingga besar nanti. SR yakin anaknya akan jauh lebih baik dari ibunya.

Subjek II meyakini bahwa dirinya mampu melewati masalah dan memiliki kehidupan yang lebih baik. Alasannya karena memiliki orang-orang selalu senantiasa ada disampingnya untuk membantunya ketika menghadapi masalah. Subjek II juga sangat yakin bahwa dirinya dapat membesarkan dan menghidupi anaknya hingga nanti.

Resiliensi lebih dari sekedar bagaimana seorang individu memiliki kemampuan untuk mengatasi kemalangan dan bangkit dari keterpurukan melainkan juga kemampuan individu untuk meraih aspek positif setelah kemalangan yang menimpanya. Kedua subjek mampu mengambil 
banyak pelajaran dari peristiwa kehamilan yang dialaminya. Kedua subjek mampu mampu memetik pelajaran yang bermakna dari peristiwa kehamilan yang dialaminya. Mereka mendapatkan pelajaran yang berharga bahwa dalam hidup seberat apapun itu masalah yang sedang dihadapi, dirinya harus menghadapi dan bertanggung jawab atas semuanya, meskipun itu resiko pahit. Selain itu kedua subjek juga ingin menjadi orang yang lebih baik dan dapat membahagiakan orang lain. Hal tersebut tentunya juga mendukung kemampuan kedua subjek dalam peningkatan aspek positif dalam dirinya.

\section{Kesimpulan}

Berdasarkan hasil penelitian bahwa kedua subjek penelitian ini memiliki kemampuan pembangun resiliensi sehingga kedua subjek mampu beradaptasi positif dengan peristiwa kehamilan tidak diinginkan yang terjadi akibat kekerasan seksual dari pasangan subjek. Kedua subjek mengalami proses kesedihan, keterpurukan dan kemudian berusaha untuk menerima kenyataan, melanjutkan kehamilan, melahirkan dan menjadi orang tua tunggal untuk anaknya. Masing-masing subjek memiliki tujuh aspek kemampuan pembangun resiliensi yang berbeda-beda.

Subjek I baik dalam meregulasi emosi dan mengendalikan dorongan-dorongan perasaan negatif atas masalah yang sedang dihadapi oleh dirinya yaitu dengan cara menenangkan diri dan menjauh dari orang lain yang dapat mengganggunya. Sehingga dengan itu subjek I dapat menemukan jalan keluar permasalahannya. Subjek I juga memiliki rasa optimis dan efikasi diri baik terhadap kehidupannya dimasa yang akan datang sebab subjek I memilih untuk melanjutkan sekolahnya yang sempat terhenti.

Sedangkan subjek II kurang dalam hal meregulasi emosi dan mengendalikan doongandorongan negatif atas masalah yang sedang dihadapi oleh dirinya sebab subjek II masih sulit mengendalikan sendiri apabila mengalami kesedihan yang meletup-letup. Subjek II juga masih membutuhkan orang lain untuk mendapatkan ketenangan dan menemukan jalan keluar terhadap masalahnya. Rasa optimis dan efikasi diri subjek II juga tidak jauh berbeda dengan subjek I namun subjek II lebih memilih untuk langsung bekerja daripada melanjutkan sekolahnya.

Faktor orang terdekat, seperti keluarga, sahabat dan masyarakat sekitar kehidupan subjek juga sangat membantu proses perkembangan resiliensi kedua subjek. Sebab, kedua subjek membutuhkan dukungan, harapan positif dan kepedulian untuk menumbuhkembangkan kemampuan-kemampuan resiliensi dalam dirinya sehingga dapat menjadi sosok remaja putri yang lebih baik darisebelumnya.

\section{Daftar Pustaka}

Ali, Mohammad dan Mohammad Asrori. (2008). Psikologi Remaja Perkembangan Peserta Didik. Jakarta: Bumi Aksara.

Apriani, Arista. Hubungan Antara Pengetahuan Tentang Resiko Kehamilan Pada Remaja di Luar Pernikahan Dengan Sikap Terhadap Hubungan Seksual Pranikah Pada Siswa SMAN 3 Magetan. (2010). Skripsi, Program Studi Kebidanan. Universitas Sebelas Maret.

Arida, I Nyoman Sukma, Kutanegara Pande Made, Basilica Dyah Putranti. Seks dan Kehamilan Pranikah Remaja Bali di Dua Dunia. 2005. Pusat Studi Kependudukan dan Kebijakan: Universitas Gajahmada Ford Foundation. 2005.

Badan Koordinasi Keluarga Berencana Nasional (BKKBN). 51 dari 100 Remaja di Jabodetabek Sudah Tak Perawan. 2010. (http://www.ceria.bkkbn.go.id/beritanasional/kepala-bkkbn-51-dari-100 remaja-dijabodetabek-sudah-tak-perawan.html) diakses pada tanggal 16 Februari 2012, pukul 09 : 48 WIB.

Badan Koordinasi Keluarga Berencan Nasional (BKKBN). Kehamilan Tidak Diinginkan Dilakukan Oleh Remaja Usia 15-25 Tahun. 2008 (http://ceria.bkkbn.go.id/ceria/penelitian/detail/495) diakses pada tanggal 19 Februari 2012, pukul 19:39 WIB.

Creswell, John W. (2009). Research Design Qualitative, Quantitative, and Mixed Approaches 3rd Edition. Thousand Oaks California: Sage Publication.

Departemen Kesehatan RI. (2007). Modul Pelatihan Pelayanan Kesehatan Peduli Remaja (PKPR).

Desmita. (2010). Psikologi Perkembangan. Bandung: PT. Remaja Rosdakarya.

Hurlock, Elizabeth B. (1980). Psikologi Perkembangan Edisi 5. Jakarta: Erlangga.

Huraerah. (2007). Dampak Sosial Psikologis Perkosaan.

http://ebookfreetoday.com/download.php?lj=http://f atur.staff.ugm/file/jurnal/ \%20Dampak\%20Sosial- 
Psikologis\%20Perkosaan..pdf) diakses pada tanggal 15 Juli 2012, pukul 10.30 WIB.

Juniarsih, Devi. Kekerasan Dalam Berpacaran. 2011.

(http:m.kompasiana.com/post/muda/2011/03/10/re maja-kekerasan-dalam-berpacaran-part-iii/) diakses pada tanggal 15 Juli 2012, pada pukul 10.00 WIB

KemenKes. Penyakit Menular Seksual. 2010. (http://kemenkes.net/datapenelitianpenyakitmenular seksual/indexx.php? module $=$ detaildata\&id $=424$ ) diakses pada tanggal 19 Februari 2012, pukul 19:39 WIB

Khodijah, Wahyu. (2010). Resiliensi Pada Siswa SMA yang Tidak Lulus Ujian Nasional. Skripsi, Psikologi Pendidikan. Universitas Negeri Jakarta.

10 Tahun Tragedi Mei 1998 Saatnya Meneguhkan Rasa Aman, Langkah Maju Pemenuhan Hak Perempuan Korban Kekerasan Seksual. (2008). Laporan Pelapor Khusus Komnas Perempuan Tentang Kekerasan Seksual Mei 1998 dan Dampaknya

Manuaba, Prof. Dr. Ida Bagus Gde. (1999). Memahami Kesehatan Reproduksi Wanita. Jakarta: Arcan.

M. M, Tugade \& B. L Frederickson. (2004). Resilient Individual Use Positive Emotion To Bounce Back From Negative Emotional Experience, Journal of Personality and Social Psychology, Volume 24, no 2.

Moloeng, Lexy J. (2007). Metode Penelitian Kualitatif. Bandung: PT Remaja Rosdakarya.

Murray. (2007). Dating Violence. http://ebookfreetoday.com/view-

pdf.php?bt=DATING-VIOLENCE-Pengertian-

DatingViolence\&lj=http://repositiry.usu.ac.id/bitstr eam/123456789/22787/Chapter\%2011.pdf) diakses pada tanggal 15 Juli 2012, pukul 10.30 WIB.

Papalia, D. E., Olds, S. W., \& Feldman, R. D. Human Developmen Edisi 8. (2001). USA: Macgraw - Hill Companis.

Poerwandari, E. Kristi. (2009). Pendekatan Kualtitaif Untuk Penelitian Perilaku Manusia. Depok: LPSP3UI.

Pontianak Post. Remaja Putri Bunuh Diri di Pontianak. 2012.

(http://www.pontianakpost.com/berita/11428-

Remaja-putri-bunuh-diri-dipontianak.html)
Prof. Dr. Sugiyono. (2008). Metode Penelitian Pendidikan. Bandung: Alfabeta.

Reivich and Shatte. (2002). The Resilience Factor 7 Essential Skills for Overcoming Life's Inevitable Obstacle. New York: Random House inc.

Riana, Dina. (2008). Gambaran Resiliensi Pada Perempuan yang Putus Hubungan Setelah Melakukan Hubungan Seksual Premarital. Skripsi, Psikologi. Universitas Indonesia.

Rice, Philip. (1999). The Adolescent Development, Relationship and Culture Edisi 9. Boston: Allyn Bacon.

Santrock, John W. (2005). A Tropical Approach To Life Span Development. New York: Mcgraw - Hill Companis.

Santrock, John W. (2002). Life Span Development Perkembangan Masa Hidup Edisi 5 Jilid 1. Jakarta: Erlangga.

Sarlito, Sarwono Wirawan. (2006). Psikologi Remaja. Jakarta: PT. Raja Grafindo Persada.

Smith, A. Jonathan. (2009). Dasar-dasar Psikologi Kualitatif. Bandung: Nusa Media.

Supardi \& Sadarjoen. (2006). Teori Kekerasan. (http://ebookfreetoday.com/view-

pdf.php?bt=TEORI-KEKERASAN-PengertianKekerasan\&lj=http://repositiry.usu.ac.id/bitstream/ 123456789/22787/Chapter\%2011.pdf) diakses pada tanggal 15 Juli 2012, pukul 10.00 WIB.

Tuapatiinaja, Josetta Maria Remila. (1998). Firo-B dan Hubungan Seksual Sebelum Pernikahan (Studi Kasus Pada Remaja Putri Yang Pernah Melakukan Hubungan Seksual Sebelum Pernikahan). Skripsi, Psikologi. Universitas Indonesia.

Wardhani, Yurika \& Weni Lestari. (2009). Gangguan Stres Pasca Trauma Pada Korban Pelecehan Seksual dan Perkosaan. Pusat Penelitian dan Pengembangan Sistim dan Kebijakan Kesehatan. Surabaya.

Yuarsi, Susi Eja. (2005). Perempuan Yang Terpuruk Kehamilan Tidak Dikehendaki di Kalangan Pengungsi. Pusat Studi Kependudukan dan Kebijakan: Universitas Gajahmada Ford Foundation. 